\title{
HARVARD SCHOOL OF PUBLIC HEALTH
}

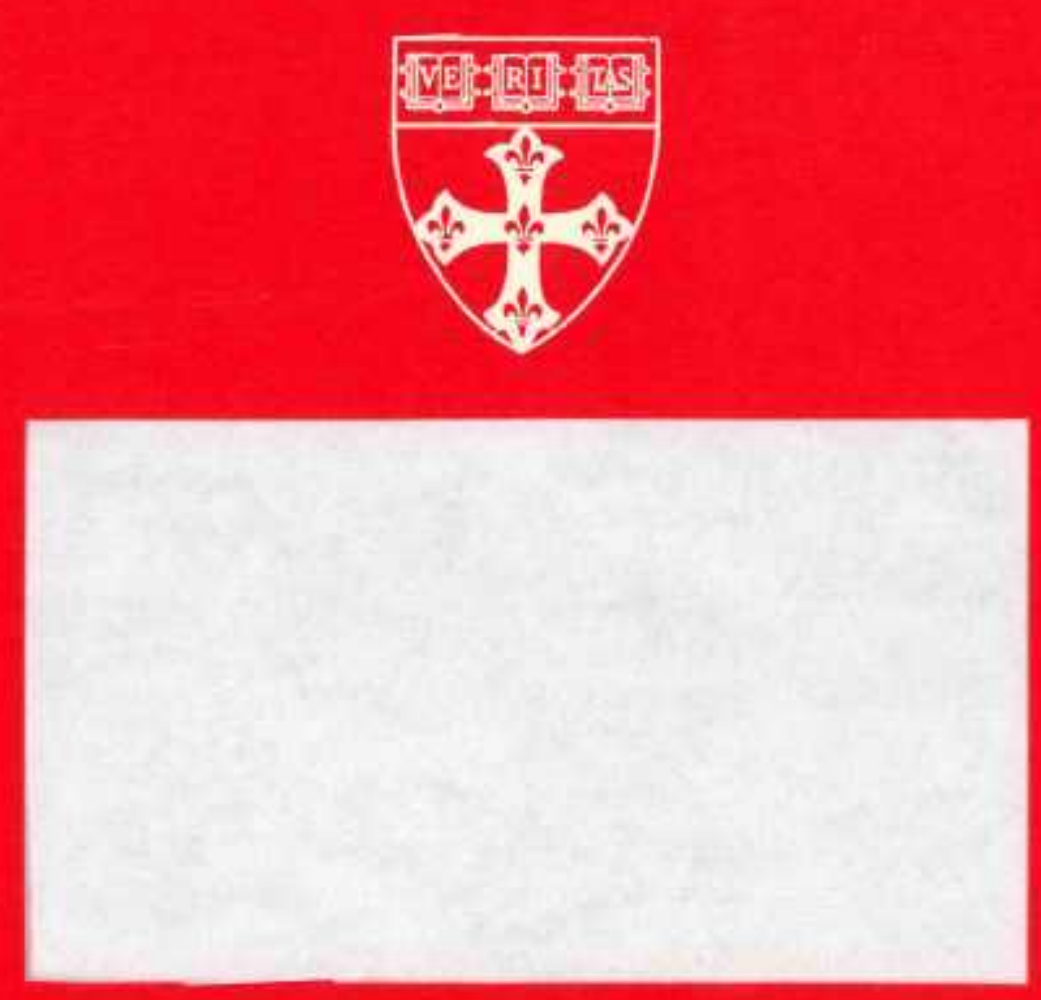

665 HUNTINGTON AVENUE

BOSTON, MASSACHUSETTS 02115 


\section{DISCLAIMER}

This report was prepared as an account of work sponsored by an agency of the United States Government. Neither the United States Government nor any agency Thereot, nor any of their employees, makes any warranty, express or implied, or assumes any legal liability or responsibility for the accuracy, completeness, or usefulness of any information, apparatus, product, or process disclosed, or represents that its use would not infringe privately owned rights. Reference herein to any specific commercial product, process, or service by trade name, trademark, manufacturer, or otherwise does not necessarily constitute or imply its endorsement, recommendation, or favoring by the United States Government or any agency thereof. The views and opinions of authors expressed herein do not necessarlly state or reflect those of the United States Government or any agency thereof. 


\section{DISCLAIMER}

Portions of this document may be illegible in electronic image products. Images are produced from the best available original document. 
LEAAL NOTICE

This report was prepared as an account of work sponsored by the United States Government. Nelther the United States nor the United States Atonic Energy Commission, nor any of the1r employees, nor any of thelr contractors, subcontractors, or their employees, makes any warranty, express or 1mplied, or assumes any legal liability or responsibllity for the accuracy, completeness, or usefulnss: of any information, apparatus, product or process disclosed, or rejpesents that $1 \mathrm{ts}$ use would not infringe privately ined rights. 
Rec1p1ent

Aerojet Nuclear Company

A1r Reduction Company

American Nuclear Soclety

Argonne National Laboratory

At omic Energy Commission, Advisory

Committee on Reactor Safeguards

Atomic Energy Commission, Brookhaven Patent Group

Atomic Energy Commission, Canoga Park Area Office

Atomic Energy Commission, Chtcago Operations

office Contracts Division

Atomic Energy Comission, Contracts Division, Cambridge

Atomic Energy Commisston, Division of Compliance

Atomic Enerty Commission, Division of Waste

Management \& Transportation

Atomic Energy Commission, DIvision of Production

Atomic Energy Commission, Division of Reactor Licensing

Atomic Energy Comntssion, Division of Reactor

Development and Technology

Atomic Energy Commisston, D1vision of Technical

Information Extension, Oak Ridge

Atomic Industrial Forum, Reactor Safety Comittee

Atomics International

Battelie Memorsal Institute

Bechtel corporation, PFTF Project

Brookhaven National Laboratory

California Institute of Technology, Pasadena

Environmental Protection Agency, Division of Survelilance and Inspection, Winchester

Environmental Protection Agency, Eastern Environmental Radiation Laboratory, Montgomery

Environmental Protection Agency, National Environmental Research Cemter, Cincinnati

Environmental Protection Agency, Offlce for Alr Programs, Rockville

Environmental Protection Agency, offlce of Radiation Programs, Rockville

Environmental Protection Agency, Western Environmental Research Laboratory, Las Vegas

General Electric Corporation, Atomic Power Equ1pment Department
No. of Copies

3

1

1

27

2

1

2

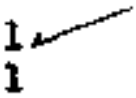

1

1

1

18

$\frac{1}{1}$

3

1

$\boldsymbol{l}$

1

1

2

11

1

I 
Iowa State College

Johns Hopkins Untversity

Kriolis Atomlc Power Laboratory

Los Alamos Sclent ific Laboratory

MPR Associates, Library

Mine Safety Appliances

Monsanto Research Corporation

North American Carbon, Inc.

National Lead Company of Oh10

Naval Research Laboratory

Oak R1dge National Laboratory, Chemical

Technical Division

Oak Ridge National Laboratory, Nuclear

Safety Program office

Oak Ridge National Laboratory, Nuclear Safety Information center

Pac1f1c Northwest Laboratories, Battelle

Hemorial Institute

Savannah River Laboratories

Teledyne Isotopes

Union Carbide corporetion

U.S. Bureau of Mines

Untverstty of California, Lawrence Berkeley

Laboratory

WADCO, FRTF Project

Westinghouse Electric corporation, Atomic

Power Division

Westinghouse Electric Corporation, Research and

Development Center

World Health Organization, Environmental

Pollution Unit 
$\operatorname{cop}-3029-8$

\title{
UNCLASSIPIED
}

\section{Harvard A1r Cleaning Laboratory \\ School of Public Health \\ Harvard Jn1 veraity \\ 665 Huntington Avenue \\ Boston, Massachusetts 02115}

\author{
c00-3019-8 \\ SEMTAMMUAL PROQRESS REPORT \\ January i - June 30,1973 \\ M. W. F1rat, A. Goldin, \\ R. R. Hall, \\ D. W. Undern11l and $\mathfrak{D}$. W. Hoeller \\ Report Issued December, 1973
}

Prepared ror the United States Atomic Energy Comalssion. Diplsion of Roactor Development and Technology, under contract Nuinber AT(11-1) 3019 
A hermetic gas booster was tested on a prolonged sodium oxide and sodium metal aerosol load. The blower performed well under the tested conditions and was capable of maintaining a flow of $1400 \mathrm{SCFM}$ at over 30 inches of water gauge. When switching from low to high speed, a gas flow control valve must be closed or the flow will exceed 1700 SCFM and the fan will be overloaded. The amount of sodium deposited in the 8 and 12 inch diameter ducts leading to and from the blowers was dotermined. These results give better data than can be predicted by theory.

Studies of the adsorption of krypton and xenon $f^{\text {in }}$ in argon were extended to low partial pressures of argon to determine the shape of the curve of adsorption coefficient vs. argon loading of charcoal at low loadings. It was found that the fali-off of adsorption was extremely $r$ yid even with very low loadings. The adscrption of the fission noble gases from nitrogen was also studied. Ceneral trends were similar to those noted in aosorption from argor and numerical values were not markedly different. The PoIanyi adsorption theory was found useful in explaining the results from both argon and nitrogen. Adsorption from a1r and from a 60:20:20 mixture of nitrogen-argon-oxygen ws; substantsily the same as for nitrogen.

The effect of decay heat on the operation of a fission gas holdup bed was. examined using a one dimensional model which is valld for the case of a small vemperature increase. The effects of axlal and radial heat conduction, convection, and radiodecay on bed temperature were taken in:o account in both the analytical solution and the numerical anglysis. An important conclusion is that a significant temperature rise can result from a falriy small, but const $t$, input of fission gas. 
TABLE OF CONTENTS

Page No.

Summary

$v$

List of PIgures

List of Tahles

v1:

v111

Deposition of Sodfum Aerosols in Centrifugal Blowers

Int roduction

Experimental Arrangement

Procedure

Results

Adsorption of Fission Noble Gaseg on Activated Charcoal

Introduction

Adsorption from Argon

Adsorption of Krypton and Xenon

from Nitrogen

Adsorption of Krypton and Xenon from

AIr and from Argon-N1trogen-oxygen

Mixture

Discussion and Future Work

Theoretical Evaluations of the Effects of Decay theat on Holdup Bed Efficlency

Introduction

Analysts

34

Future Work.

37

Re ferences

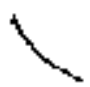

42 


\section{LIST OF FIGURES}

Figure No.

1

2

3

4

5

6

7

8

9

10

11

12
T1tle

Page No.

Experimental equipriont for sodium deposition studies

3

Thermocouple imbedded in motor f1n

Sodium aerosol deposits on blower motor

Sodfum aerosol deposits in motor compartment

9

Sodium aerosol depostts in impeller compartment

Ef fect of Argon loading on Krypton adsorption

19

Effect of pressure on Argon adsorption

Varlation of $\mathrm{Kr}$ and $\mathrm{Xe}$ adsorption with pressure

24

Temperature var1ation of adsorption of $\mathrm{Kr}$ and $\mathrm{Xe}$

Polanyi plot for Nitrogen adsorption on charcoal

Effect of N1trogen loading on

Krypton adsorption

29

Calculated temperature increase

from fission gas input as a function

of time and axial distance

38 


\section{LIST OF TABLES}

Toble No:

1

$t$

2

3

4

5

6 :

7

8

9

10

12

\section{n1tle}

Sodium Deposited on Blower Parts

Aag and Fiptor Cesing Temparatures

Durting the Third Expertnent

Blower Pexformance and lest

Cond1tions

Sodium Deposited In Plpes and Bloter ab $x$ or Total sodium Pessed Through the Syatert

Mdarption of Hoble aases rom Argen

Adaorpeton of Argon

Adsorption of Noble Gases Frow N1trogen

Adarption of Hoble Gases from Afr 30

Adsorption of Noblo Gases frov Mitrogen-Argon-Oxy gen

Falues Dsed to Calculate Temperatur Increase in a Fibsion Ca Adsorption Bed

Comparizon of Numerie and Analytic Solutions for the Average Increate Resulting froik Decay Heat
11

28

21

23

32

8

13

\section{5}

10

40 
I. Depostition of Sodiun Aerosols in

Contrifugal Blowers

M. W. First and R. R. Hall

A. Introduction

Our previous reports (1-4) described laboratory

investigations of the rate of deposition of freshly generated sodtum aerosol particles in fliters, ducts, and heat exchangers. Thls report covers investigations of sodium aerosol particle deposition in a full-scale centrifugal blower selected for service in the recirculating cooling systems of closed loop cells of the FFTP and in the duct leading into and eway from the blower.

closed loop cells in the PPTF contain major sodium recirculation equipment and must be cooled to protect the machinery enclosed in the space from overheating. Plans call for the atmosphere instde the cell to be nitrogen with no more than 15 oxygen. Th1s atmosphere will be recirculated continuously through an external heat exchanger by a centrifugal blower. Because leakage of molten sodium from the equipment inside the closed loop rell will generate sodium oxlde aerosols and metallie sodium aerosols when the sodium spill is of sufficlent magnitude to consume all avallable oxygen in the sealed space, the system must be protected from excessive deposition of aerosol particles in the heat 
exchanger and blower if the cooling function is to be maintained during and after a sp111?

B. Experimental Arrangement 、

Sodium oxide aerosol was generated in a $3300 \mathrm{ft}^{3}$ chamber contrainting less than $1.2 \%$ oxysen; the remainder being nitrogen. In our previlous experiments, a rectangular steel pot w1th four 2000-watt electrical heaters imbedded In the bottom was used to evaporate about 5 pounds of sodlum per experiment. For this series, a second pot wes needed ta make it possible to evaporate 12 pounds of sodiur. The new pot was constructed with heaters imbedded in the sides of the pot instead of in the bottom, as previously, because It was observed that a thick scale-like deposit of oxide formed on the bottom of the sodfum eveporation pot and interfered sertously with heat transfer from the heaters to the molten sodium pool. When this occurred, the reststance heaters overheated and burned out rapidly. Detalls of the aerosol chamber and the manner of generating sodium aerosols can be found in our previous reports.

Pigure $l$ is a photograph of the system used to test aerosol deposition in the recirculating blower. To the right of the plcture is the wall of the chamber in which the aerosol was generated. The fan that was tested, a Spencer Gas Booster, catalog number GH-1010-HMOD, is in the center with 


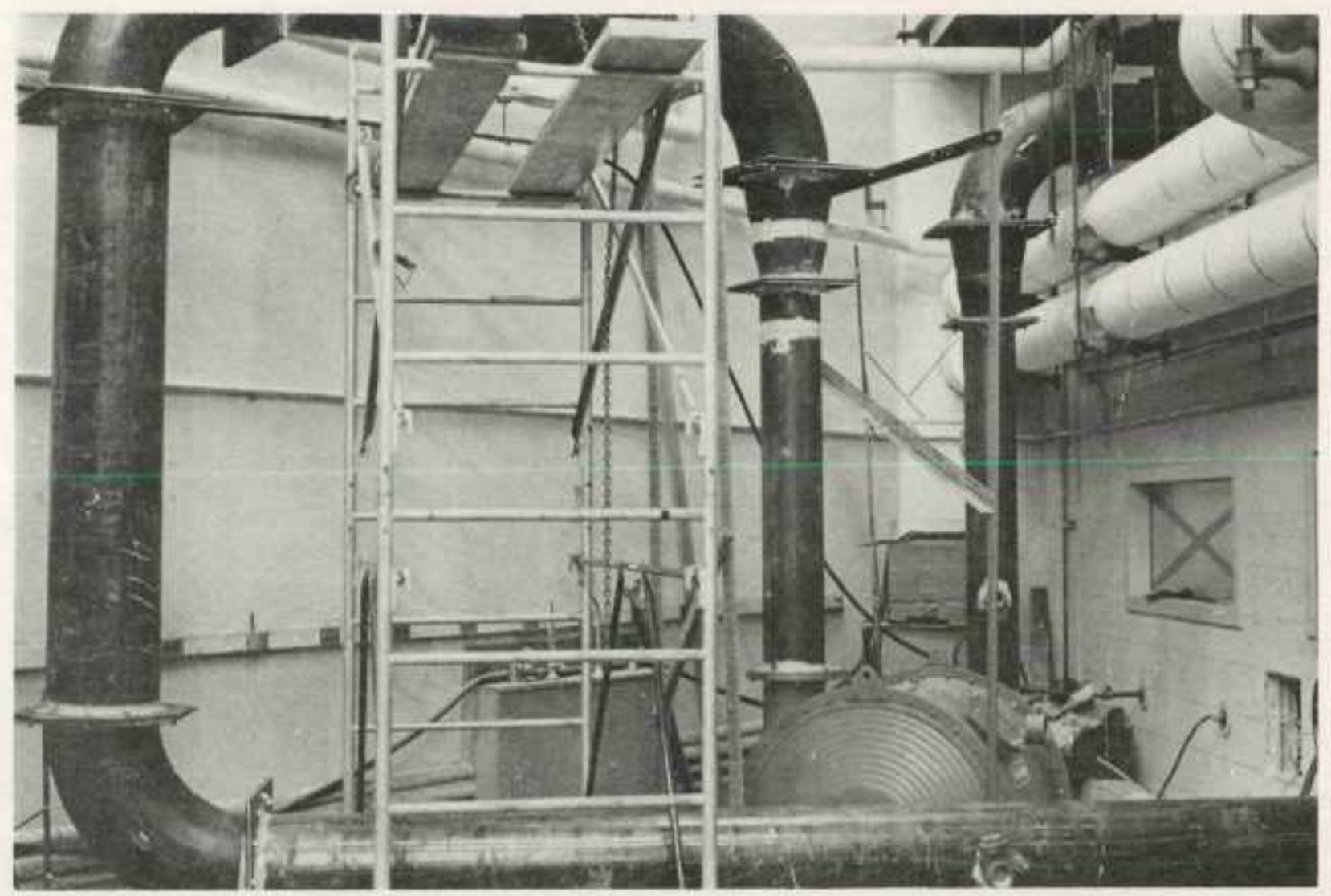

FIGURE 1 Experimental equipment for sodium deposition studies

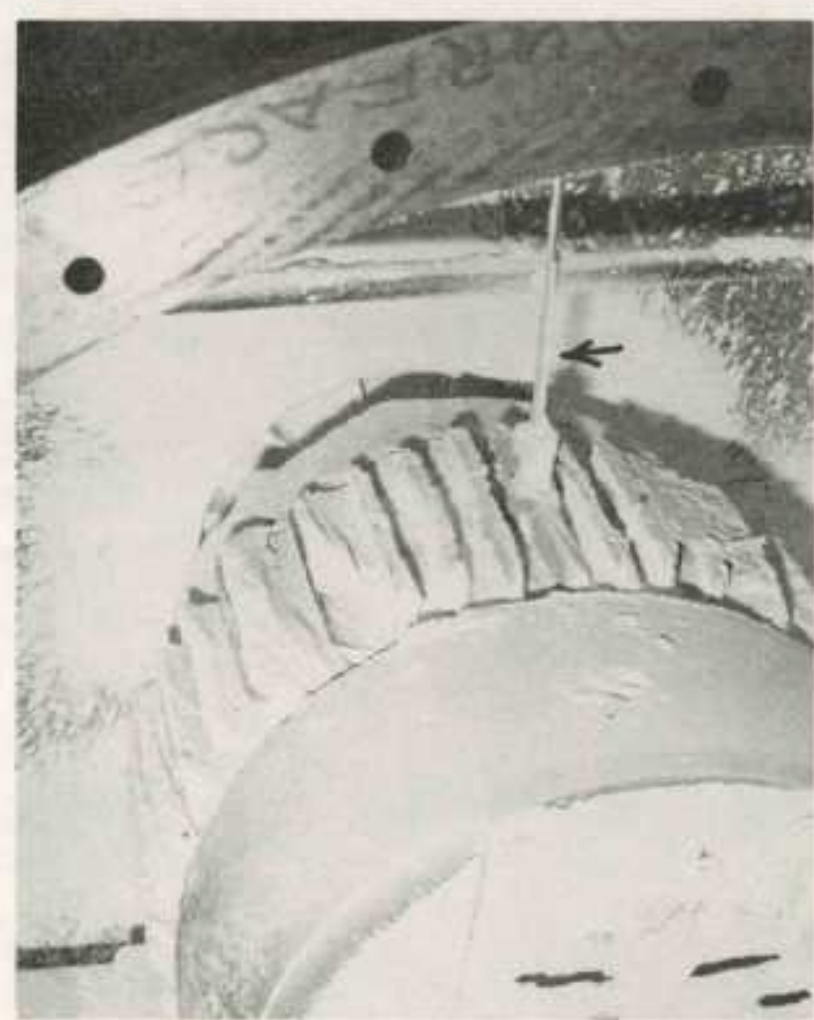

FIGURE 2 Thermocouple imbedded in motor fin

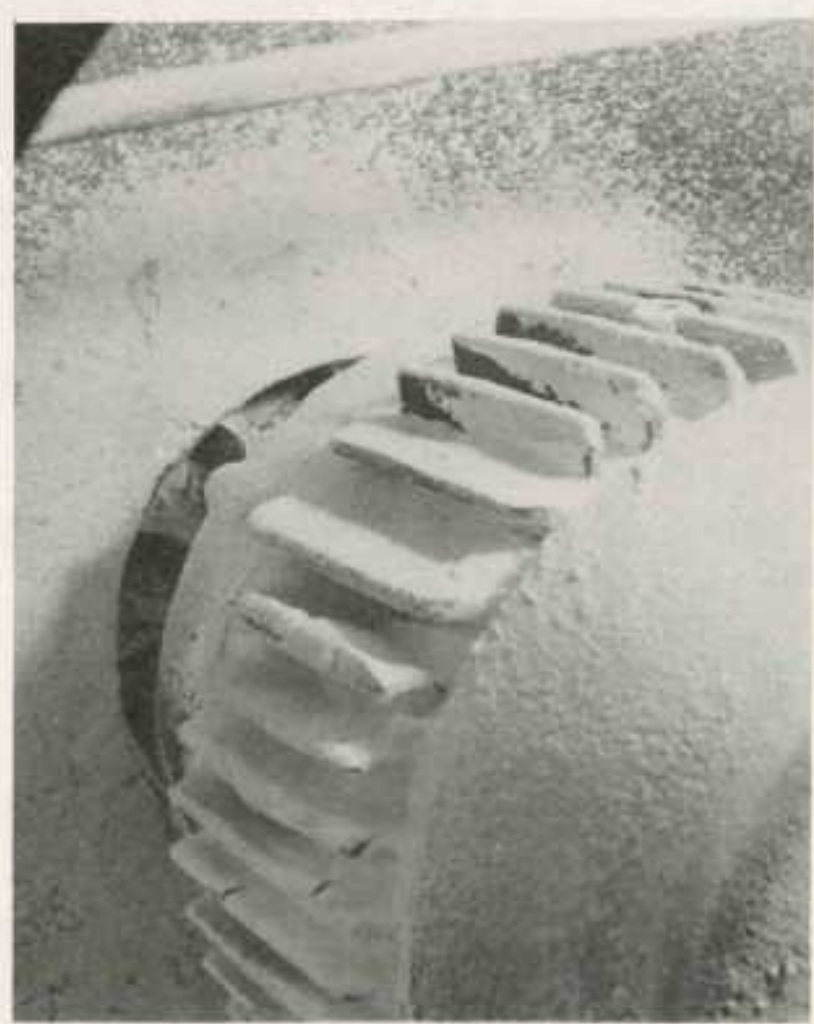

FIGURE 3 Sodium aerosol deposits on blower motor 
the discharge in front. Aerosol' was recirculated from the top of the aerosol chamber to the blower and retumed to the bottom of the chamber through large black iron p1pes. These were 8- and 12-1nch diameter, thin walled, ilanged steel pipes with $1 / 4$-inch $0-r 1 n g$ gaskets between the fluntus. mittser controls Company's 12-inch butterfly valves were used at the two chamber ports to seal the chamber when aerosol was not recirculated. The entry valve can be seen in the upper right hand corner of the picture. A port for aerosol loading and particle size sampling was located in the 8 -inch diameter yeritical pipe entering the blower. It can be seen in the photograph behind the vertical perforated angle brace. Pressure taps were Installed before and after the thower to measure pressure 1ncreàse across the fan as a signal that deposttion was occurring. The pressure change across the 8-to-12Inch expansion plece located above the fan outlet was used to measure the gas low rate after it had been cal1brated by pilot-static tube traverses. A second sampling port, located in the 12-1nch hirizontal discharge plpe, may be seen in the foreground of the plcture.

Gas temperature was measured by thermometer before and after the blower. Amperage drawn by the blower motor was measured with an Amprobe meter. Two thermocouples 
Installed In the motor housfng, shown in Figure 2, were used to monitor temperature rlse in the motor in response to the 1nsulating effect of deposited aerosol particles. A gas chromatograph was used to monitor oxygen concentration.

c. Frocedure

The first step was to charge sodium metal to the evaporation pots. This was done by pushing slices from one pound bars of sodium metal through 2-inch diameter - ports in the chamber wall and allowing them to fall into the pots below. The metal was heated to $1600^{\circ} \mathrm{F}$. After an opaque white cloud (approximately $1 \mathrm{~g} / \mathrm{m}^{3}$, expressed as elemental sodium) had formed in the chamber, the blower was started. During all experiments the butterfly valve at the inlet side of the blower remained fully open and the return air butterfly valve was used to maintain gas flow at 1400 SCFM. For 1400 SCFM, the control valve was less than 1,4 open. Running time ror each of this serles of experiments was from 3 to 10 hours at constant gas flow rate.

Durling the early part of each experiment, the aerosol particles were sodium oxtde, but later all of the oxygen was consumed and sodium metal aerosol particles formed that deposited in the system. Therefore, before the plping and fan could be disassembled safely, the deposited sodium metal had to be converted to a safe compound. 
Therefore, sodium metal was reacted with a reclrculated stream of nitrogen containing water vapor and carbon diox1de to form sodium carbonate and hydrogen according to the following reaction:

$$
2 \mathrm{Na}+\mathrm{H}_{2} \mathrm{O}+\mathrm{CO}_{2}+\mathrm{Na}_{2} \mathrm{CO}_{3}+\mathrm{H}_{2}
$$

A hydrogen meter was used to measure the generated hydrogen. When no more hydrogen was being generated, the reaction was complete. This procedure worked well. It was described In detail in a previous report. (5)

After all of the sodium metal had reacted, the system was disassembled. Parts of the fan were washed with measured volumes of distilled water and the wash water analyzed by flame photometry to measure the amount of sodium deposited on each part. Each piece of pipe was analyzed in a similar manner for deposited sodiun.

D. Results

Blower performance during three experimental runs was simllar. At the start, the pressure drop across the blower averaged $35.5 \mathrm{in.k.g.} \mathrm{Dur1ng} \mathrm{the} \mathrm{experiments,}$ pressure acrosg the blower tended to drop slightly in response to increasing temperature of the recirculat1ng gas. It averaged $32.9 \mathrm{in.w.g.} \mathrm{at} \mathrm{the} \mathrm{end.} \mathrm{Gas} \mathrm{temperature} \mathrm{at} \mathrm{fan} \mathrm{exit}$ was $18-21.5^{\circ} \mathrm{Figher}$ than at the blower entrance and reached a maximum of $150^{\circ} \mathrm{F}$. No problems were encountered 
In malntaining a constant flow of 1400 SCFM.

The quantity of aerosol that passed through the reclrculation loop varied. The first experiment, run for $313 \mathrm{mln}$, at $1400 \mathrm{SCFM}$, had an average aerosol loading of $2.5 \mathrm{gfa} / \mathrm{m}^{3}$. Therefore, a total of 30,000 grams of sodium went through the system. One of the o-ring gaskets glipped during the second experiment, causing a large air leak, and it had to be terminated after only 184 minutes of muning time. The average loading during the second experiment was $1.21 \mathrm{gNa} / \mathrm{m}^{3}$ and 8,600 grams of sodium went through the system. The f1nal experiment was run for 621 minutes. The average loading was $1.05 \mathrm{gNa} / \mathrm{m}^{3}$ and 25,000 grams of sodium passed through the system. Blower performance, as measured by a1r volume rate, pressure development, and current draw, was unaffected. throughout each experiment.

A total of 620 grams of sodium was deposited in the blower during the first experiment. A very large percentage, $71 \%$, of the deposited sodium was on the cylindrical fan nousing, the motor, and the center divider. The amounts of sodium deposited on the several interior parts of the blower are listed in Table 1 . Figures 3 and 4 show sodium deposits on the fan motor after they had been converted to $\mathrm{Na}_{2} \mathrm{CO}_{3}$. Only 11.6 grams of sodium, 1.95 of the total deposit, was found on the fan impeller. V1sual inspection, Plgure 5, of the area near the fan Impeller and of the 
SODIUM DEPOSITED ON BLOWER PARTS

TABLE 1

Granis $\mathrm{Na}$
\% of Blower of $\mathrm{Na}$ Deposit Throughput

1. Entranoc head plate
2. Cylindrical blower
housing, motor and
deflector

3. Impeller

444

71

3.5

11.6

1. 9

0.04

4. Deflector and plece between 1mpeller and spacer

$75-200$

16.3

0.33

5. Exit head plate and spacer

$$
49.6
$$

$\frac{8.0}{100.0}$

0.27

2.10 


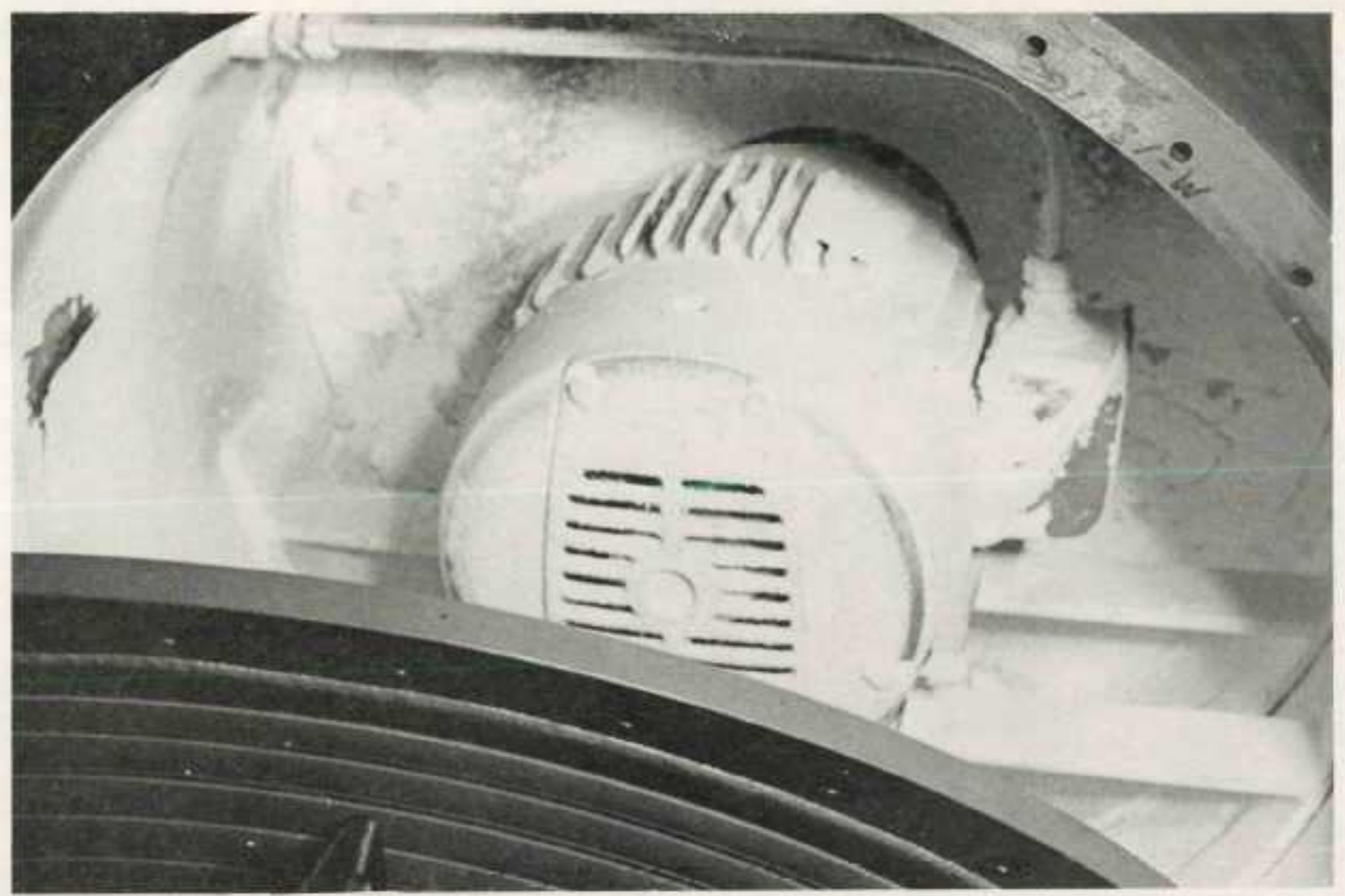

FIGURE 4 Sodium aerosol deposits in motor compartment

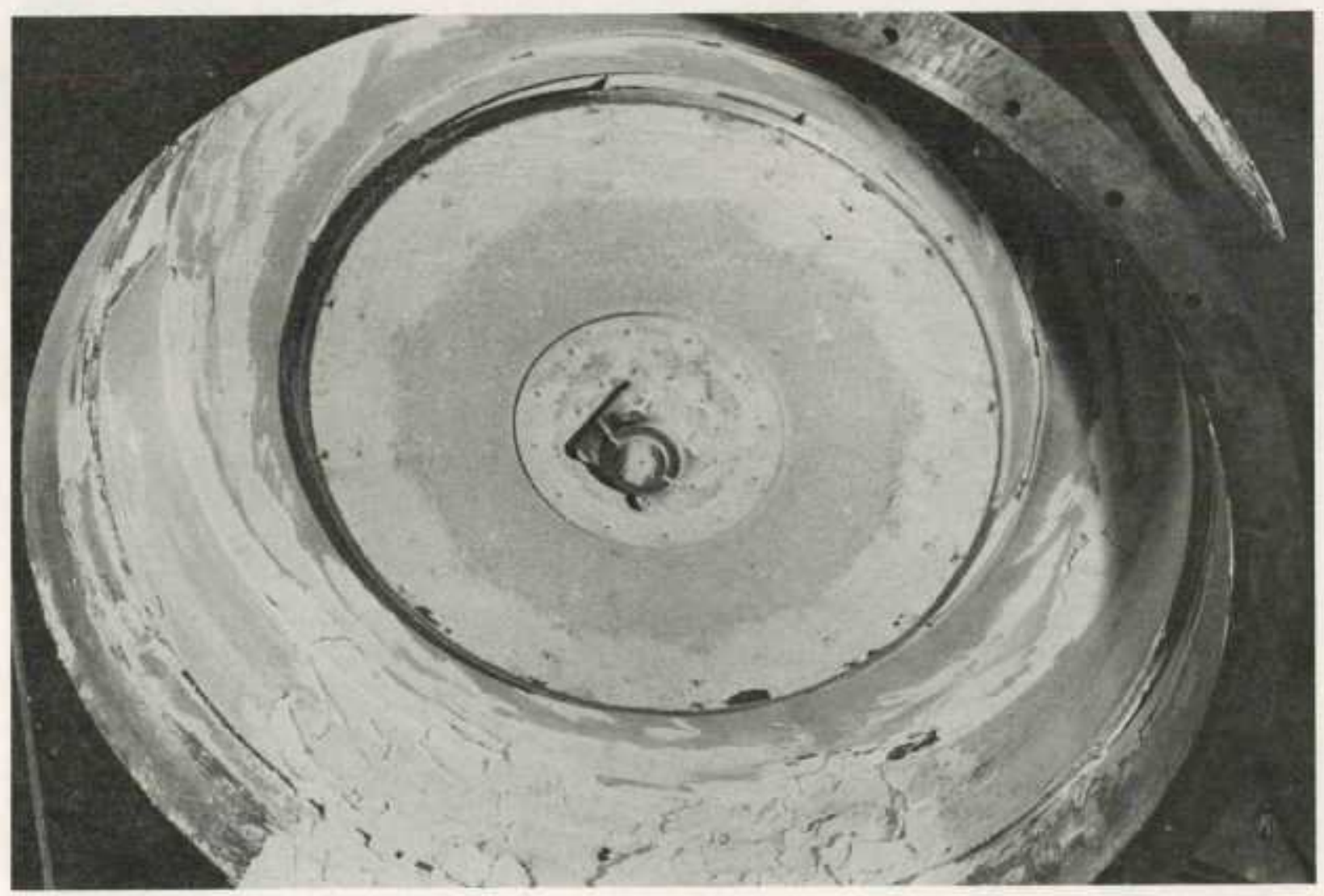

FIGURE 5 Sodium aerosol deposits in impeller compartment 
fan. Impeller itself confirm the small amount of sodium deposited in this area and Indicate that sodium deposition on the impeller should not be a problem in the FFTF closed 200 p recirculation systems.

Additional data were collected on the performance of the blower motor, a totally enclosed, 3 phase, 480 volt, 15 horsepower, two speed motor. During these experiments the motor was run only at high speed, 3600 RPM. Motor current was measured, between 14.8 and 15.8 amperes; varlations were attributed to flow adjustments to compensate for gas temperature changes during the experiments. The two thermocouples in the blower motor casing, shown in Figure 2, gave 1dentical temperature readings. Tempergture rose from $72^{\circ} \mathrm{F}$ to $162^{\circ} \mathrm{F}$ during the first 130 minutes of operation. After a total of 621 minutes runing t1me, the motor casing temperature was $191^{\circ} \mathrm{F}$, $95^{\circ} \mathrm{F}$ above the gas temperature. When the motor was turned off, the motor casing terperature went over $212^{\circ} \mathrm{F}$. A rise in temperature after the motor was shut off indicates that the motor core temperature was over $212^{\circ} \mathrm{F}$. Table $211 \mathrm{sts}$ the rise in motor temperature and simultaneous 1nlet and outlet gas temperatures.

A malfunctioning flowmeter resulted in the termination of the flrst experiment after 312 pinutes. When the flowmeter falsely indicated a flow rate below 1400 SCFM and the control valve was opened to admit more afr to the system, the motor 
GAS AND MOTOR CASING TEMPERATURES

DURING THE THIRD EXPERIMENT

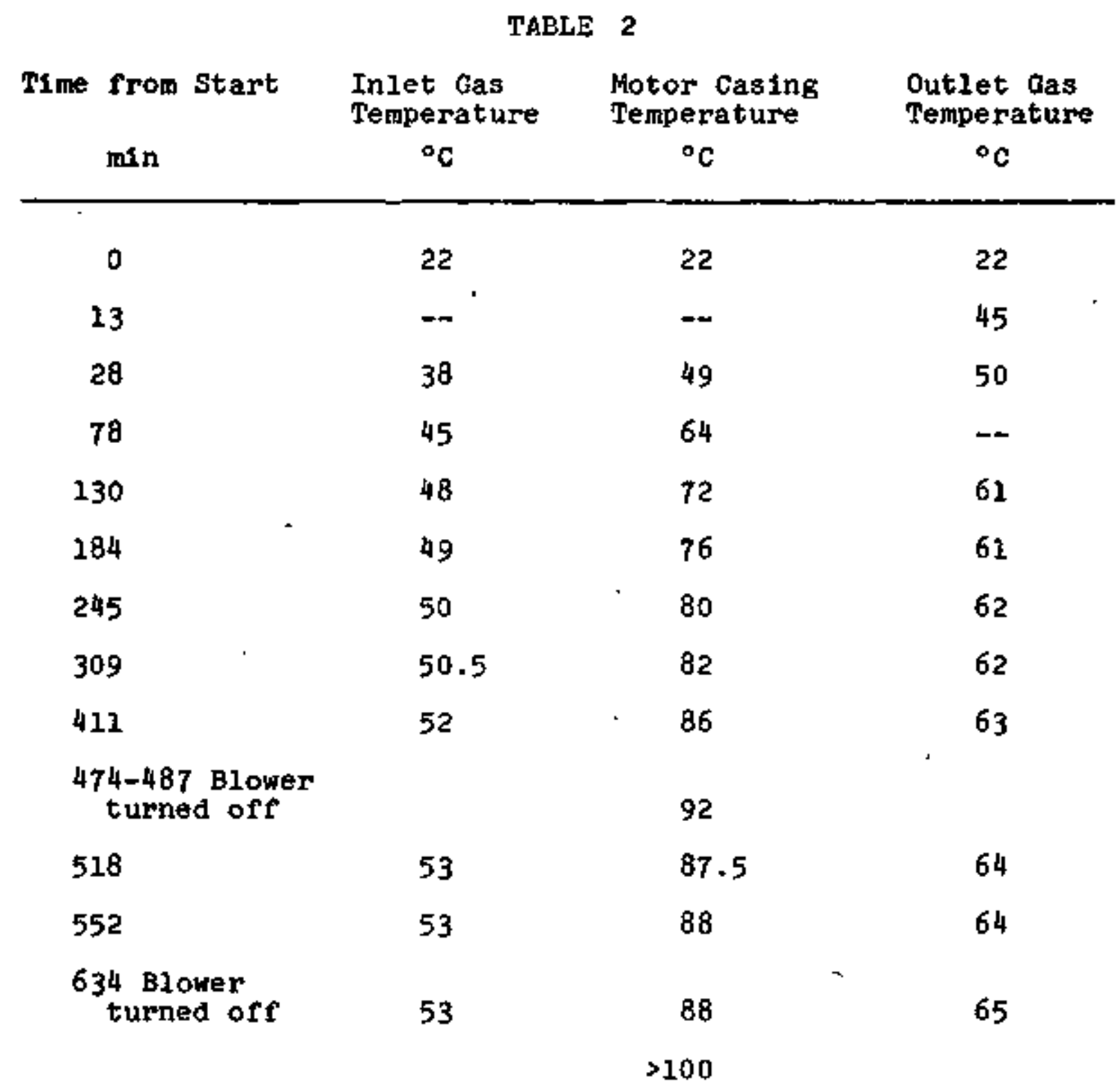


beciame overloaded and shut off, ending the experiment. During later experiments 1 t was found that the flowmeter pressure taps tended to piug and produce ralse flow readings. The characteristics of this type of blower are such that the 15 horsepower motor was overloaded when the flow exceeded 1700 SCFM. Table 3 1s a summary of blower performance and test conditions during the three experiments.

Sadium oxfde aerosol was formed at the begluning of each experiment but during the later stages the aerosol particles were metall1c sodium. The change in composition was evidenced by a change in the color of the aerosol from white to dark grey. Immediately after the first experiment, a part of the piping system was opened and, upon contact with the air, the deposit began to burn. The system was resealed promptiy with a nitrogen atmosphere and the sodium was reacted to the carbonate form in the manner previously noted. A change to sodium metal aerosol was observed about half way through the first and second experiments. Oxygen concentration for the f1rst experiment was $1.2 \%$ at the start and $0.34 \%$ at the end. For the second experiment, 1t was $2.15 \%$ at the start and $0.55 \%$ at the end. During the third experiment, oxygen was added perfodically to the chamber to avold the formation of sodium metal aerosol. The percent oxygen in the chamber was maintained between $0.7 \%$ and $1.2 \%$, averag1ng $0.9 \%$. However, after about three hours, the aerosol became grey and remained grey during the rema1nder of the expertinent. 
BLOWER PERFORMANCE AND TEST CONDITIONS

TABLE 3

Experiment tho.

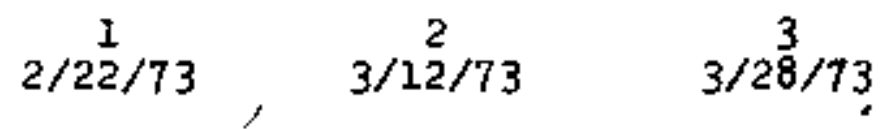

Flow - SCFH
Running Time - Min.
BIower Pressure Drop-in.w.g.

Start

34.3

35.2

36.8

End

$32 \cdot 3$

$134 \mathrm{~min}$

1,400

313

184

621

Motor Amps

Start

End

\begin{tabular}{|c|c|c|}
\hline- & $14.8-15.2$ & $15.2=15$. \\
\hline 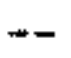 & $14.8-15.2$ & $15.2-15$. \\
\hline
\end{tabular}

Gas Temp at End- ${ }^{\circ} \mathrm{C}$

Fan Inlet

$\cdot \div-$

Fan outlet

$>60$

$51.5 \mathrm{at}$
$147 \mathrm{~min}$

53

65

Motor Casing Ternp.

at End- ${ }^{\circ} \mathrm{C}$

- -

$--$

88

Average Loading gila $/ \mathrm{m}^{3}$

2.5

1.21

1.05

Grams Na Put Through System 30,000

8,600

25,000

Oxygen - $\%$

Start

1.2

1.15

1.05

End

0.3

0.55 at

$15^{4} \mathrm{~min}$

I.05

$\mathrm{CO}_{2}$ was

added) 
Particle deposition in the ducts leading to and from the blower was measured. (These measurements were made so that radiation exposures to workers required to perforts emergency procedures in the vicinity could be calculated. Table 4 lists the total amount of sodiun that passed through the system and the percent deposited in each piece of plpe during each experiment. Also listed, is the average percent deposited. Because the percent of sodium deposited in the several sections varied widely from experiment to experiment, the most reliable figure 1s, thought to be the average percent deposited, This is listed in the last column of Table 4. Vartations in the percent of sodium deposited can be attributed to flow disturbances caused by poorly fitting flanges that differed slightly between experimenta and loss or deposited sodium during the reaction pertod and during dtsassembly. 
SODIUM DEPOSITED IN PIPES AND BLOWER

AS $\$$ OF TOTAL SODIUM

THAT PASSED THROUGH THE SYSTEM

TABLE 4

Parts Listed from Inlet to outlet $2 / 22 / 73$

$3 / 12 / 73$

$\underset{7}{3 / 28 / 73} \quad$ Average

1. Valve race, 12" spool

plece, 12" elbow and

$12 " \times 8^{\prime \prime}$ reducer

0.052

0.10

0.10

0.084

2. 8" $\times 62 "$ downpipe

0.052

0.17

0.064

0.095

3. 8" elbow

0.029

0.058

0.067

0.051

4. 8" $\times 16-1 / 2 "$ Inlet

plpe to olower

0.027

0.022

0.022

0.024

5. Blower

2.2

7.65

3.14

4.3

6. 8" $8^{\text {" } 54 " ~ e x i t ~ p l p e ~}$ from blower

0.096

0.14

See 14

0.12

7. 8" $\times 12^{\prime \prime}$ expanding section

0.025

0.035

See 14

0.030

8. 12" elbow above blower

0.027

0.023

See 114

0.025

9. 12" $\times 61$ " overhead pipe

0.056

0.036

0.054

0.049

20. 12 " elbow

0.027

0.019

0.026

0.024

11. $12 " \times 69 "$ downpipe

0.038

0.087

0.053

0.059

12. 12 " elbow

0.025

0.074

0.060

0.053

13. $12 " \times 138 "$ test

section

0.10

0,28

0.17

0.183

14. Total of 6,7 , and 8

0.148

0.198

0.24

0.20

Total Sod1um Throughput, grams

30,000

8,600

25,000 
II. Adsorption of Pission Noble Geses

On Activated Charcoal

$$
\text { A.. S. Goldin and H. A. Trindade* }
$$

\section{A. Introduction}

Recent work at the Harvard School of Publlc Health on the adsorption of fission noble gases on charcoal has been concentrated on adsorption from argon at high pressures and low temperatures. $(3,4)$ By applying the Polanyl adsorption theory ${ }^{(6)}$, we have shown that large reductions in; adsorption result from coverage of a relatively small fraction of the charcoal with carrier molecules.

Data obtained on very small beds at Harvard have been In good agreement with those obtalned by Kabele ${ }^{(7)}$ on p1lot plant sized equipment. This gives us confidence in the validity of laboratory data for design purposes.

B. Adsorption from Argon

Adsorption of ission product xenon and krypton on activated carbon from argon carrier gas has been reported. in our last two progress reports. Anomalous behavior at low temperatures and high pressures was reported by Ratney and Underbil1. (3) This anomily consisted of abnormaliy low and even negative slopes of the adsorption coefriclent vs. pressure curves, especially at low temperatures. Thio was

- Un1versidade Federal Do Rio De Janeiro, Rio de Janetro, Brazil 
expleined by Underhi11, Goldin, and Trindade (4) as being due to Increased occupation of adsorption sites by ilquid (or quas1-11qu1d) argon and consequent compet1t1on between rlssion gas and argon at the h1gh pressures and low temperatures 1nvloved. The Palanyi adsorption theory $(6)$ was used to calculate' the argon adsorption.

During the current period, this work was extended to lower partial pressures of argon. These results, uth a few additional new data points at higher partial pressures, are 1 isted in Table. 5. The low partial pressures were obtained by $3: 1$ dilution with helium so that the pressure of argon at a total pressure of 5 psig was $0.3^{4}$ atmospheres (aboolute). Figure 6 shows the variation of the pressure normalized adsorption coefficient of krypton as a function of the volume of argon adsorbed on the charcoal. The value for zero coverage was taken from data on the adsorption of krypton rrom helium. Figure 6 may be compared with Figure 2-7 of reference (4). It will be seen that the added data at 2ow partial pressures of argon define the lert hand side of the curves more accurately and show the extremely rapid decrease in adsorption coefficlent with inftial argon loading of the charcoal.

The adsorption of argon 1tiself is of interest for the hold-up of argon-41. Values of argon adsorption coeffictents at temperatures from $-75^{\circ} \mathrm{C}$ to $-140^{\circ} \mathrm{C}$ and pressures from 1.3 
TABLE 5

Adsomption of Noble Gases from Argon

KRYPTON

XENON

\begin{tabular}{|c|c|c|c|c|c|}
\hline Temp. & $\begin{array}{l}\text { Absolute } \\
\text { Pressure } \\
\text { otm }\end{array}$ & $\begin{array}{l}\text { Adsorption } \\
\text { Coefftatent } \\
\text { I(STP)/g }\end{array}$ & $\begin{array}{l}\text { Temp. } \\
{ }^{\circ} \mathrm{C}\end{array}$ & $\begin{array}{l}\text { Absolute } \\
\text { Pressure } \\
\text { atm }\end{array}$ & $\begin{array}{l}\text { Adsorption } \\
\text { Coerftetent } \\
\text { I(STP)/R }\end{array}$ \\
\hline-140 & $0.34 *$ & 32.9 & & & \\
\hline-120 & $0.34 *$ & 24.8 & & & \\
\hline-100 & $0.34 *$ & 6.93 & & & \\
\hline-20 & 3.04 & 0.33 & & & \\
\hline+23 & 1.29 & 0.061 & +22 & 3.04 & 1,83 \\
\hline+24 & 3.04 & 0.123 & & & \\
\hline
\end{tabular}

0.34 atmospherea partial pressure of Ar, from a 25:75 Ar-He mixture at 5 poig $(-1.34$ atm) 


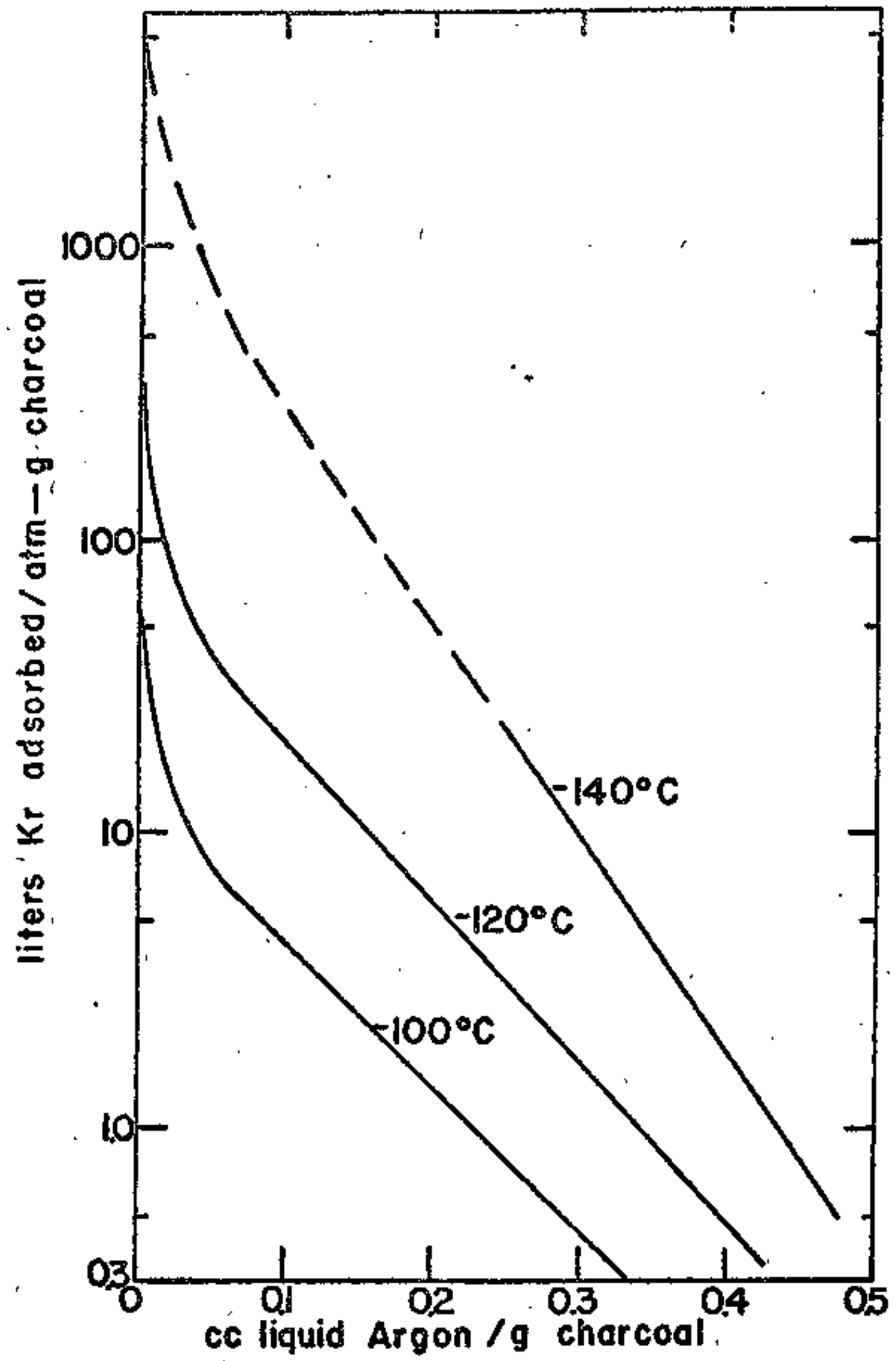

FIGURE 6 EFfect of ARgon LOAding. On Krypton adsorṕtjon 
to 19 atmospheres have been renorted ${ }^{(4)}$. These values were extended to amblent $\left(+25^{\circ} \mathrm{c}\right)$ temperatures and all are $11 \mathrm{sted}$ in Table 6. The polnts at $-78^{\circ} \mathrm{C},+25^{\circ} \mathrm{C}$, and 0.34 atmospheres have not heen previously reported. All these data are nlotted In Fifure 7. The preater slope of the pressure dependence curve at amblent temperature is apparent.

c. Adsorption of Krypton and Xenon from Nitrogen

In some FFTP envirorments, nitrogen can become contaminated with rission kryotons and xenons. Fxoeriments were accordinely performed to determine the characteristics of adsombion of the re rases from nitropen. These experiments were carried out from ambient temperature town to $-100^{\circ} \mathrm{C}$ and at nressures from 1.3 atmosnheres ( $5 \mathrm{ps} 1 \mathrm{p}$ ) to 5.76 atmosnheres (70 os 1f) + Xenon measurements were not made at temneratures beloy $-50^{\circ} \mathrm{C}$. These results are plven in Table 7. Plpure $\theta$ shows the adsorption coefrictents for both elements as a function of oressure for the various temoeratures. The decrease in pressure dependence at the lower temperatures is cleariy shown. The adsorntion coefficients or krunton and xenon from nitroren are not very different from those obtained for these elements from armon carrier ras. These relationshtns are shown a ittle more clearly in wirue 9 in which the adsorntion coefficients at 1.3 atmospheres and 3. n atmospheres are plotted afalnst $1 / T$.

The Polanvi procedure, whtch bad been successtud in correlatinf. the edsorption data of krypton over a wide rante 
TABLE 6

\section{Adsorpt1on of Argon}

\begin{tabular}{|c|c|c|c|c|c|}
\hline Temp. & $\begin{array}{l}\text { Absolute } \\
\text { Pressure } \\
\text { atm }\end{array}$ & $\begin{array}{l}\text { Adsorption } \\
\text { Coeffic1ent } \\
1(S P P) / g\end{array}$ & 'Temp. & $\begin{array}{l}\text { Absolute } \\
\text { Pressure } \\
\text { atm }\end{array}$ & $\begin{array}{l}\text { Adsorption } \\
\text { Coeffictent } \\
\text { I(STP) } / Q\end{array}$ \\
\hline \multirow[t]{6}{*}{-140} & $0.34 *$ & 0.194 & -75 & $: 0.34 \%$ & 0.032 \\
\hline & 2.68 & 0.257 & & 3.72 & 0.119 \\
\hline & 3.72 & 0.284 & & 5.76 & 0.136 \\
\hline & 5.76 & 0.287 & & 7.79 & 0.159 \\
\hline & 7.79 & 0.294 & & 10.51 & 0.174 \\
\hline & 10.51 & 0.307 & -78 & 5.76 & 0.140 \\
\hline-120 & $0.34^{*}$ & 0.118 & & 7.79 & 0.155 \\
\hline \multirow[t]{7}{*}{-115} & 1.34 & 0.176 & & 1.00 & 0.0055 \\
\hline & 1.68 & 0.181 & +25 & 3.72 & 0.020 \\
\hline & 3.72 & 0.214 & & 6.44 & 0.032 \\
\hline & 5.76 & 0.235 & I & 10.54 & 0.049 \\
\hline & 7.79 & 0.243 & & & \\
\hline & 30.51 & 0.256 & & & \\
\hline & $0.34 *$ & 0.068 & & & \\
\hline \multirow[t]{5}{*}{-100} & 1.68 & 0.139 & & & \\
\hline & 3.72 & 0.174 & & & \\
\hline & 5.76 & 0.190 & & & \\
\hline & 7.11 & 0.200 & & & \\
\hline & 10.51 & 0.217 & & & \\
\hline
\end{tabular}

0.34 atmospheres partial pressure of Ar, from a 25:75 Ar-He m1xture at 5 psig $(=1.34$ atm) 
FIGURE 7

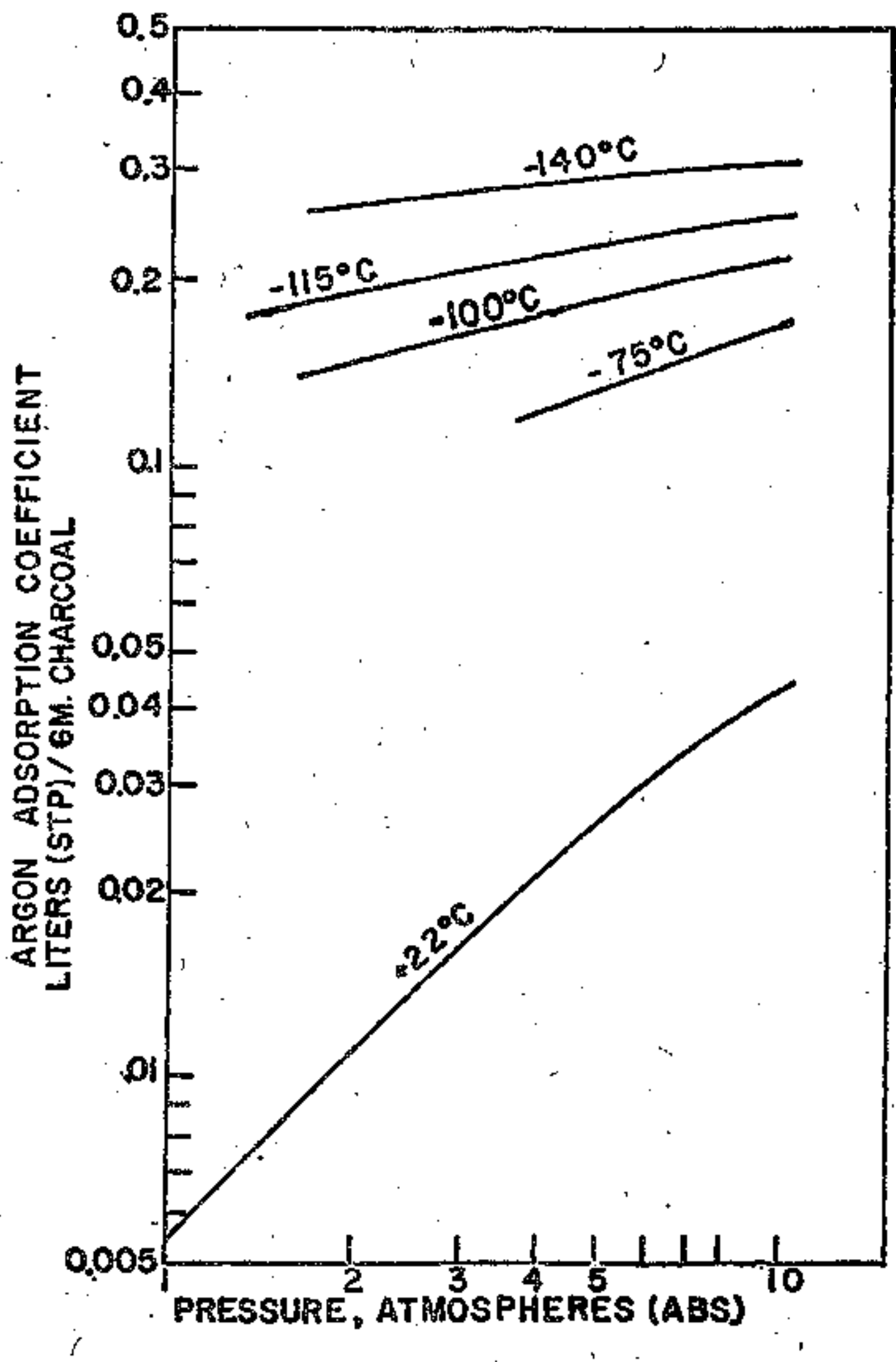

EFfect of pressure on ARgon adsorption 
TABLE 7

Adsorption of Noble Gaises from Nitrozen

KRYPTONON

Temp. Absolute Adsorption

${ }^{\circ} \mathrm{C}$ Pressure Coefficlent, atm

1 (STP) $/ 8$

$-100$

1.29

2.07

1.95

2.40

3.04

2.58

5.76

2.80

$-50$

1.29

2.00

0.53

3.04

0.62

$-20 \quad 1.29$

1.68

0.28

0.22

2.90

$+25$

1.29

2.00

10.29

3.04

0.061

0.085

0.115
Temp. Absolute

${ }^{\circ} \mathrm{C}$ Pressure atm

$-50$

$-20$

1.29

3.04

17.9

21.0

4.73

2.00

5.94

3.04

1.29

2.00

3.04

$+22$

6.79

0.97

1.27

1.62
Adsorption Coeffictent $1(\mathrm{STP}) / \mathrm{P}$ 


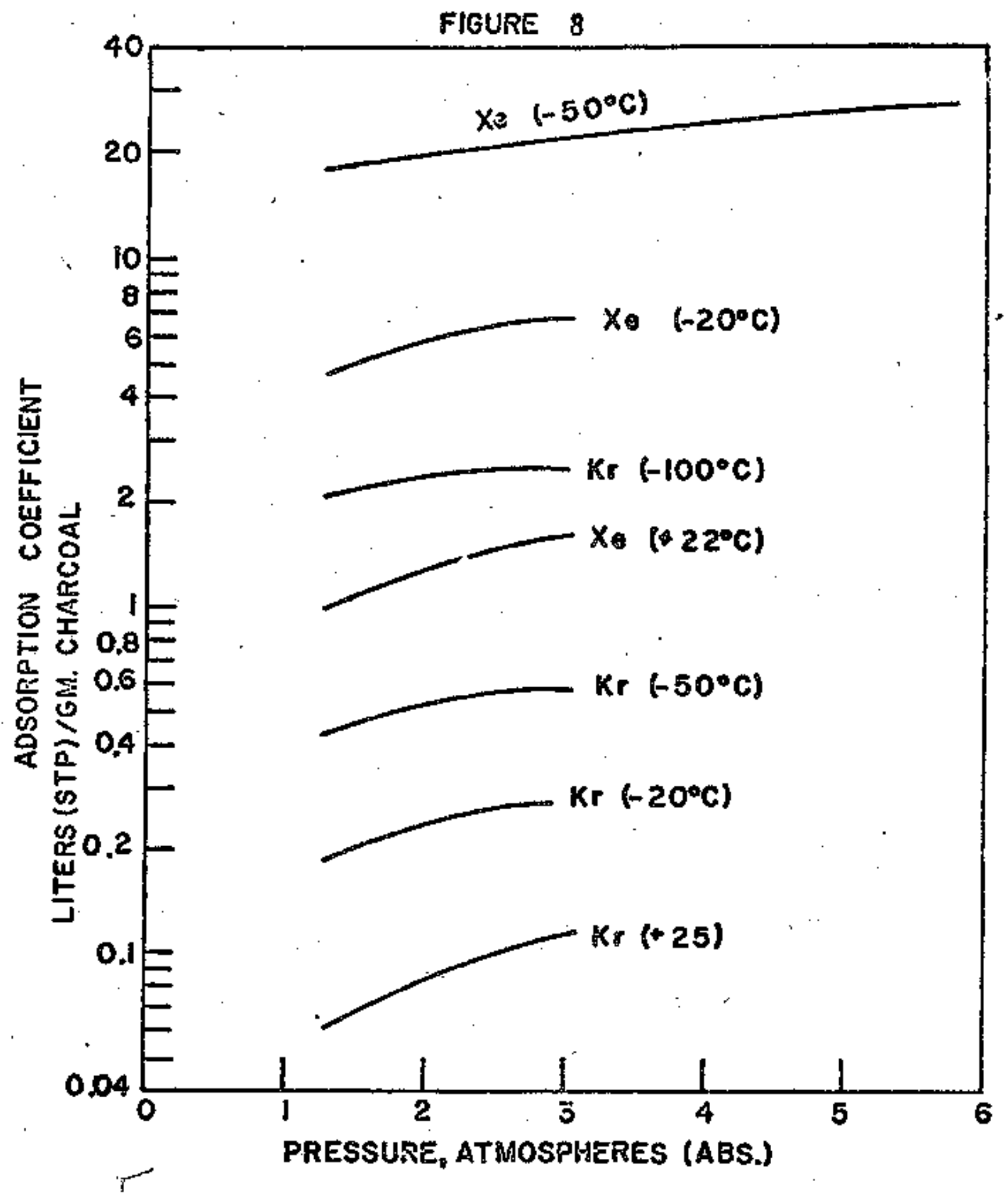

VARIATION OF KR AND XE ADSORPTION WITH PRESSURE 


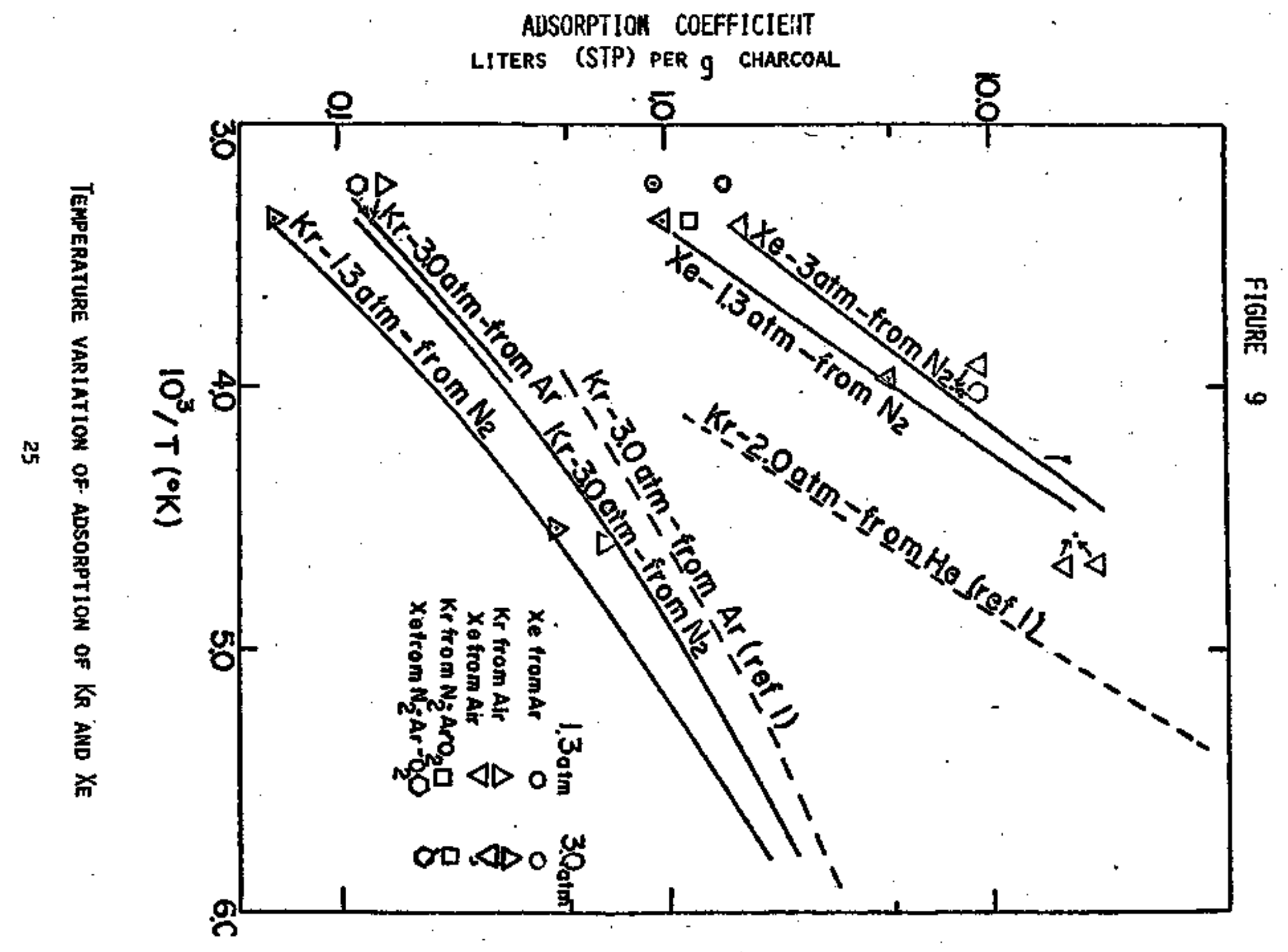


of temperature and pressure, was apolied to the adsomption Fron nftropen. Jecessary data were obtalned by mexsurins. the adsorption of nitrogen on activated charcoal at various temperatures and pressures. The charcoal bed was broupht to equidibrium with nftropen at the temperature and pressure of interest, and then the volume of n1tropen desorbed when the bed yas allowed to come to room temperature and pressure was mensured. A correction was applied for restdual atsorption at room temperature ant presgure and for dead space in the bed. The results are shown in Fipure 10. The ordinate 1s the volume of nitropen adsorbed per 100 prams of charcoal expressed as cub1c centimeters of 11 quid nitropen at the temperature at which the vapor oressure woild be equal to the adsorstion pressure. The absc1ssa is $\left(T / v_{h}\right) 10 r_{10}\left(f_{s} / f\right)$ in. which $\mathrm{T}$ is the absolute temperature, ${ }^{a} \mathrm{~K} ; \mathrm{V}_{\mathrm{b}}$ 1s the nolar volume of liquefied nitrogen at the adsorption pressure, $\mathrm{cm}^{3}$; and $r_{s}$ and $f$ are the furacities of $n i t r o p e n$ liquid at adsomtion temperature and of the nitropen gas, respectively. since the measurements were made above the critical temoerature of mitropen, pressure and fukacity of the liould phase were obtained by extrapolation.

The nttropen loadinp data of Flpure lowere used to correlate the adsorntion data of krypton from nitropen. To do this, the adsorption coefficlents (normalized to unt mressure) pere plotted apalnst. the volume of l1qufd (or nuas1-Ifqu1d) nitropen adsorbed at the particular temperature 


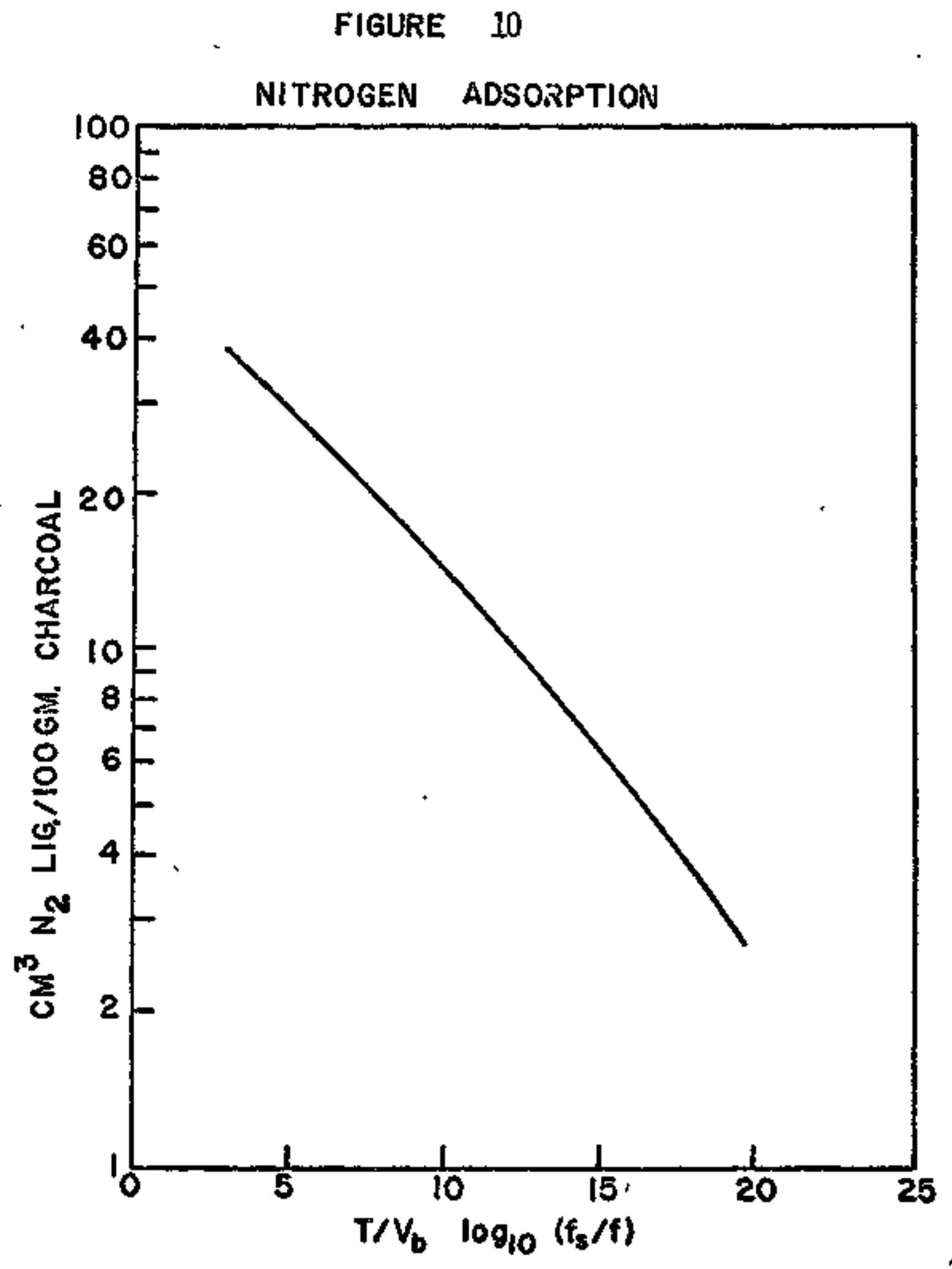

POLANY PLOT FOR HITROgEN ADSORPTION ON CHARCOAL 
and nressure. These data are presented in Fipure 11. As in Fipure 6, the zero coverare polnt was obtained from hellum cover ras data. One curve for adsorption from arpon (at $-100^{\circ} \mathrm{c}$ ) is incluted for comparison. The peneral similarity In shape of the curves relating krypton adsorption coefriclents to coverape of charcoal by Ilquia nitrofen (Fipure 11) to those melatinp coefficients to coverate by Ifquid arron (plfure 6) $1 \mathrm{~s}$ striking. In both sets of curves, there is a very marked decrease in noble gas adsorption with inttial coverage of the charcoal, followed by a much slower decrease wth-further coverage. The difference between the argon curve at $-100^{\circ} \mathrm{C}$ and the nitrogen curve at $-100^{\circ} \mathrm{C}$, althouph small, 1s real. It had been our hope that these eurves of kryoton adsorption vs. coverage would be Identical for a1fferent rases, and so useable for prediction, but this hope was not fulfilled.

D. Adsorption of Krypton and Xenon from $A 1 r$ and from Argon-N1trogen-Oxygen Mixture

Some inleakage of air into the nitrogen cover gas which was the concern of the previous section must be exnected. According, ly the adsorption of krypton and xenon from mixtures of nitromen and oxymen ranping from 0 to $20 \%$ oxyren could be 1mportant. In1t1al measurements were made with $20 \%$ oxyfen (alr). Table 8 olves these data. The adsorption was found to be not almnificantly different from that observed from nitrofen carrier pas. Accordingly, it was coneluded that the adsorptions from nitropen and from nitropen-oxypen mix- 


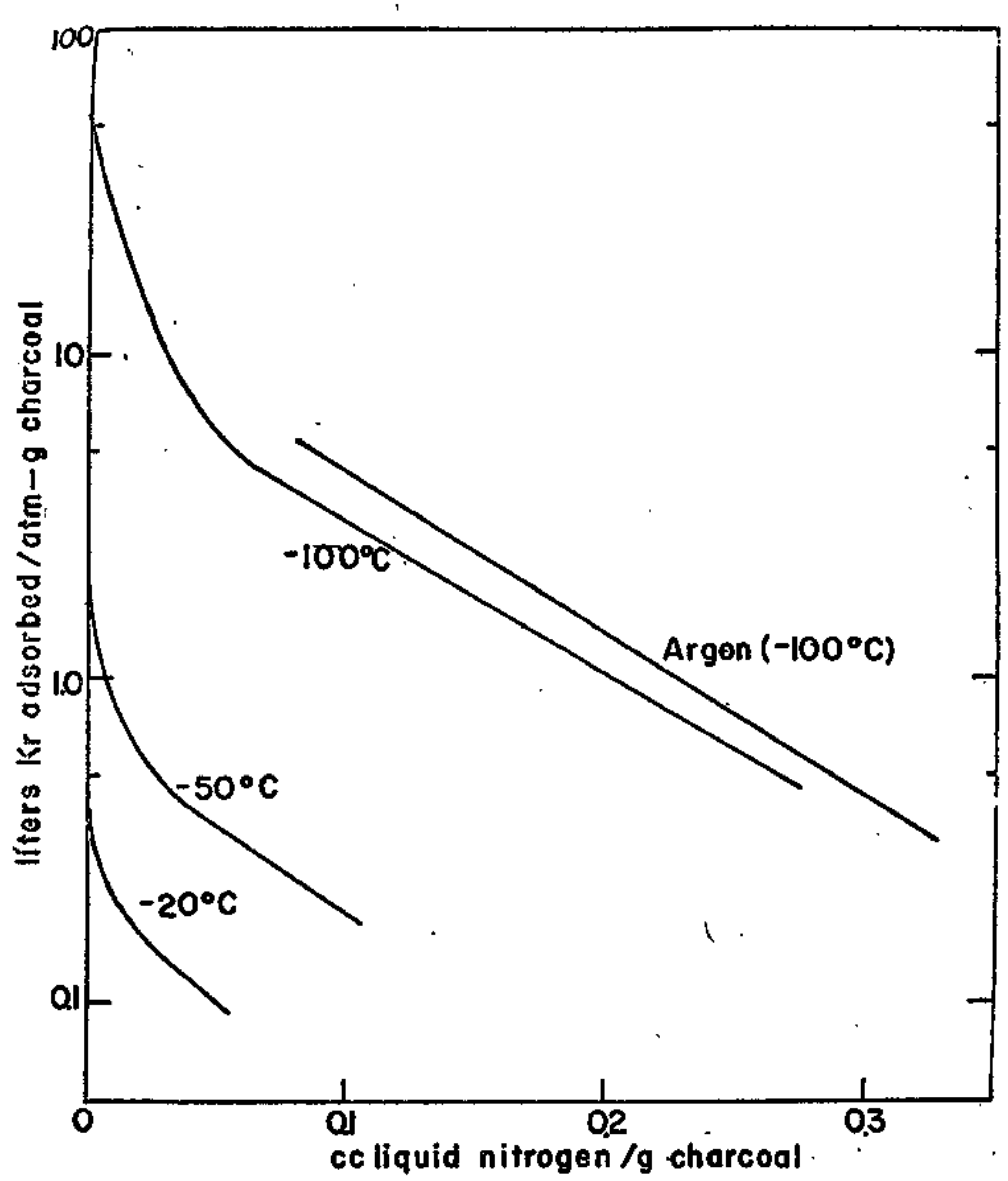

FIGURE 11 Effect of NI TROGEN LOADING ON KRYPTON aDSORPIION 


\section{TABLE 8}

\section{Adsorption of Noble nases from A1s}

\section{KRYPTON}

Temp

Absolute

Pressure

ato

Adsorption Coefrioient 1 (STP)/G

$-50$

1.29

3.04

$+25 \quad 1.29$

2,00

3.04

$$
1(S T P) / \mathrm{s}
$$

0.45

0.64

0.060

0.088

0.125
$-50$

Tenp. ${ }^{\circ} \mathrm{C}$

-20
+22

XENON

Absolute Adsorption

Pressure atmo Coefricient 1 (STP)/g

17.2

19.7

4.73

6.79

0.96

3.04

1.70 
tures, at least over the ranke of concern, were essentlally equi valent, and no experiments on intermediate mixtures were made.

Some measurements were also made of the adsorption of the two noble pas elements from a 60:20:20 mixture of n1troren-arpori-oxyren. The similarity in adsorption coefriciento between araion and nitropen and the Identity between the coefflelents from nitrogen and from a1r led us to expect little or no difference in adsorption from this mixture, as compared with nitropen. Early data, presented in Table 9, conryrmed these expectations, and accordinf,ly the experiments were tarminated.

E. Discussion and Future Work

The investigations of fission gas adsorption on charcoal have been directed towards hold-up of the gases on a bed for delay. This concept is useful for short-lived nuclides such as all the radiokryptons except krypton-85 (longest halr-11fe - 28 hours and for essent1ally ali the radioxenons. Xenon 133 has a 5.3 day hal f-11fe, but xenon $1 \mathrm{~s}$ retalned better than krypton. Xenon-129m and xenon-132m, w1th half-1ives of 8.0 and 12.0 days respectively, are produced in very small ylelds. The removal of krypton-85 from effiuents, especially from fuel reprocessing effluents, has been suggested of ten, beginning in the middle to late $1950 \cdot \mathrm{s}^{(8,9,10)}$. Several processes have been investigated for the separation, including lowtemperature adsorption on charcoal (11), absorption in organic 


\section{TABLE 9}

Adsorption of Noble Gases from H1trogen-Argon-Oxygen

$(60: 20: 20)$

\section{KRYPTON}

Temp.

${ }^{\circ} \mathrm{C}$

$-70$

$-20$

$+24$
Absolute

Pressure

atm

3.04

3.04

3.04
Adsorption Coerficient $I$ (STP) $/ B$

$$
1.14
$$

0.31

0.121
XFNON

Temp. Absoiute Pressure atm

Adsorption Coetficient 1 (STP) $/ g$

$-20$

3.04

7.16

$+22$

1.72 
solvents $(10)$, cryogen1c d1st1liation ${ }^{(12)}$, and passage through permselective membranes (13). Removal by pressure swing sorption-desorption appears to of ter advantages in simplictty of equipment and operation. The techntque has been applied for "heatless crying" of alr ${ }^{(13)}$ and a preilminary application to concentration of krypton -85 has been reported ${ }^{(14)}$. Briefly, the technique involves a four-step cycle: (1) pressurization of bed with carrier gas, (2) passage of blgh pressure contantnated carriẹ gas unt13 Just before breakthrough, (3) depressurization, and (4) backwash with clean carries gas at low (atmosphersc) pressure to remove 831 contaminant in concentrated form. The clean carrier gas produced in step (2) is divided into two parts (a) a pure "product" which in this case can be discharged to the environment, and $(0)$ the backflush carrier for step (4). Investigations of feasibilfty with both charcaal and inorgante beds are tri process. 
III. Theoretical Evaluations or the Erfecta of Decay Heat on Holdup Bed Efficlency

D. W. Underhill

\section{A. Introduction}

There to at present no complete mathematical solution avallable for caloulation of the tewperature fise in a fision gas holdup bed. The basic difficulty is the nondinear erfect of temperature on the adsorption coefrielent. Glueckar (1959) round an analytic golution for a nonlinear radial distribution of fision gas resulting from the radial temperature diatribution, but this solution neglects other factors, 1neluding the channeling of hot gases through the center of the bed making it less useful then would irst appear.

B. Analys1s

Our analys1a began with the following differentiel equation (F1rst, et al. 1970) whtch gives the offects of radial and axial heat conduction, convection, and radion sct1ve decay on the average bed temporature at a distance, $x$, from the inlet.

$$
\begin{aligned}
& k \frac{\partial^{2} t_{I}}{\partial x^{2}}-\gamma \frac{\partial t_{I}}{\partial x}-B t_{I}+q_{I^{e^{-\alpha}}}{ }^{-\alpha} I^{x}=\rho c_{k} \frac{\partial t_{I}}{\partial \tau} \\
& \text { where } c_{k} \text { - heat espacity of charcoel, cal/gm- } \mathrm{C} \text {. } \\
& c_{p} \text { weat capacity of carrier gas at conotant } \\
& \text { * thermal conductivity of the charcoal, }
\end{aligned}
$$




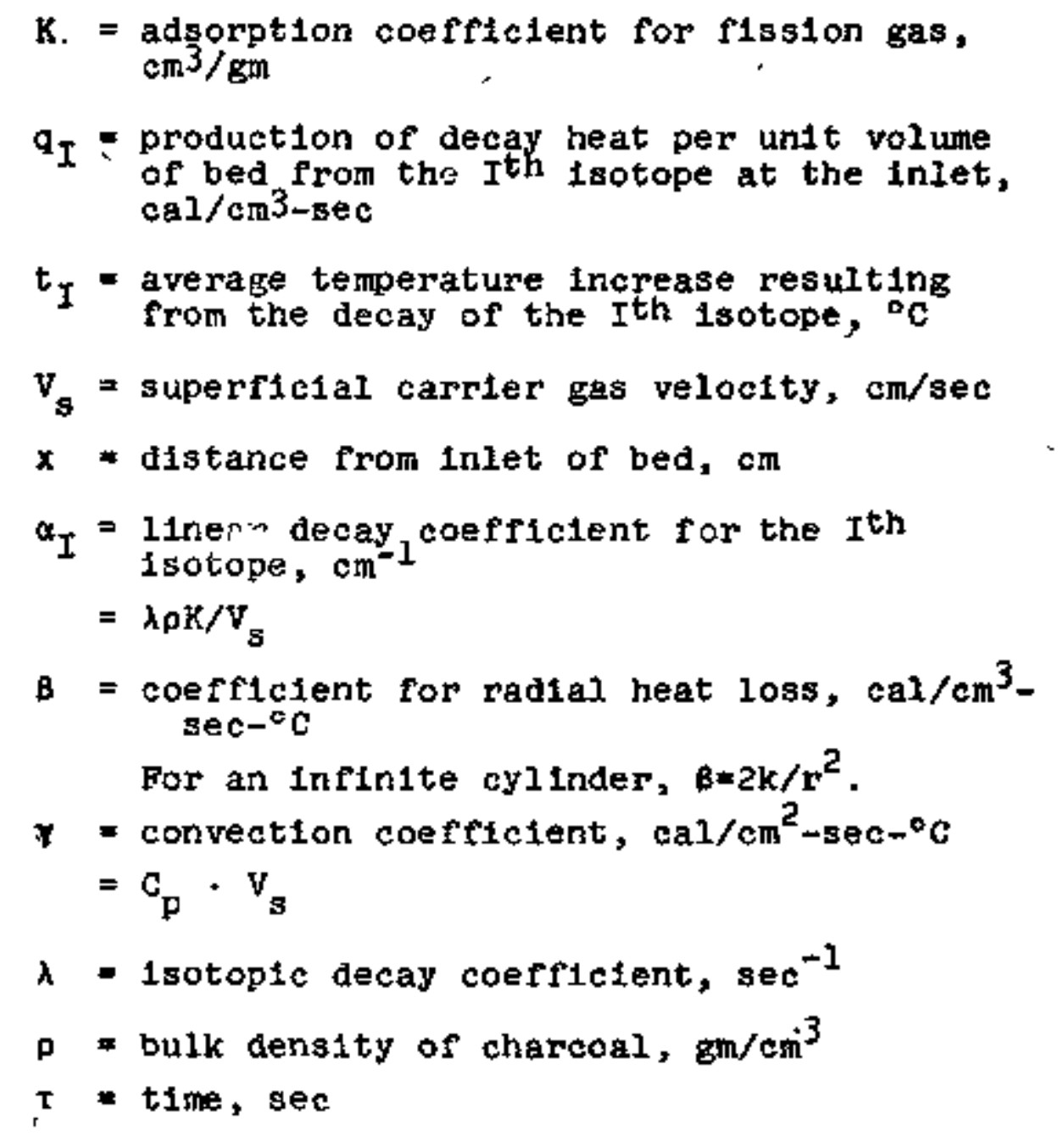

Assuming that the temperature rise is small, the adsorption coefficient will remain constant across the bed. At steady state, $\frac{\partial t}{\partial I} I=0$ and the above differential equation can be integrated to give

$$
\left.t_{I}=\frac{q_{I}}{B-\alpha_{I} \gamma-\left\{a_{I}{ }^{2}=k\right.}\left(e^{-\alpha_{I} x}-e^{\left(\gamma \gamma^{2}+4 \beta k\right.}-\gamma\right) x / 2 k\right\} .
$$

A general solution to the problem of decay heat can be obtained by numerical analysis with a digital computer. 
At present we have only a one dimension model with a constant adsorption coefficient, $1 . e$. , a numerical equivalent of the analytical solution we have just described. These computer calculations replace the differential equation with the foilowing difference equation for $t_{I}(x)$, the temperature increase resulting from decay of the $I^{\text {th }}$ lsotope at a distance, $x$, from the inlet.

$$
\begin{aligned}
k & \left(t_{I}(x-\Delta x)+t_{I}^{*}(x-\Delta x)-2 t_{I}(x)-2 t_{I}^{*}(x)=t_{I}(x+\Delta x)\right. \\
& \left.+t_{I}^{*}(x+\Delta x)\right) / 2 \Delta x^{2}=y t_{I}(x+\Delta x)+t_{I}^{*}(x+\Delta x) \\
& \left.-t_{I}(x-\Delta x)-t_{I}^{*}(x-\Delta x)\right\} / 4 \Delta x-b t_{I}(x) \\
& \left.+t_{I}^{*}(x)\right) / 2+q_{I} e^{-a_{I} x}=\Delta c_{k}(t *(x)=t(x)) \Delta t
\end{aligned}
$$

where $\Delta x=$ Incremental distance, cm

$$
\begin{aligned}
\Delta t & =\text { incremental time, sec } \\
t_{I}(x) & =t_{I}(x) \text { at time } \tau+\Delta \tau
\end{aligned}
$$$$
\text { The set of simultaneous equations describing the }
$$
temperature Increase across the bed is then solved by use of the tridiagonal matrix procedure described by Westlake (1968). We assumed, in making these computer calculations, that both the Inlet and effluent gas temperatures were controlled by coming into contact with cold walls; in contrast, the analytical model discussed earlier assumed a semi-1nfin1te adsorption bed with only one cold end. Figure 12 shows the heating in an adsorption bed following arsteady state Input of a fission gas mixture in an argon carrier gas starting 
at time $\tau=0$. The numerical values used in this calculation are 11sted in Table 10. Table 11 glves a compartson between the steady state numerical and analytical solution. Where the difference in boundary conditions can be Ignored, the agreement is quite close.

v. Future Work

It would be useful to extend this numerical analysis to a more general analysis which can take into account the difference in the adsorption coefficient brought about by radial and axial heating. A particularly interesting result would be to extend this model to the polnt where it can be used to follow the effect of a sudden release of a large number of curies of fission gas lsotopes into an adsorption bed. 


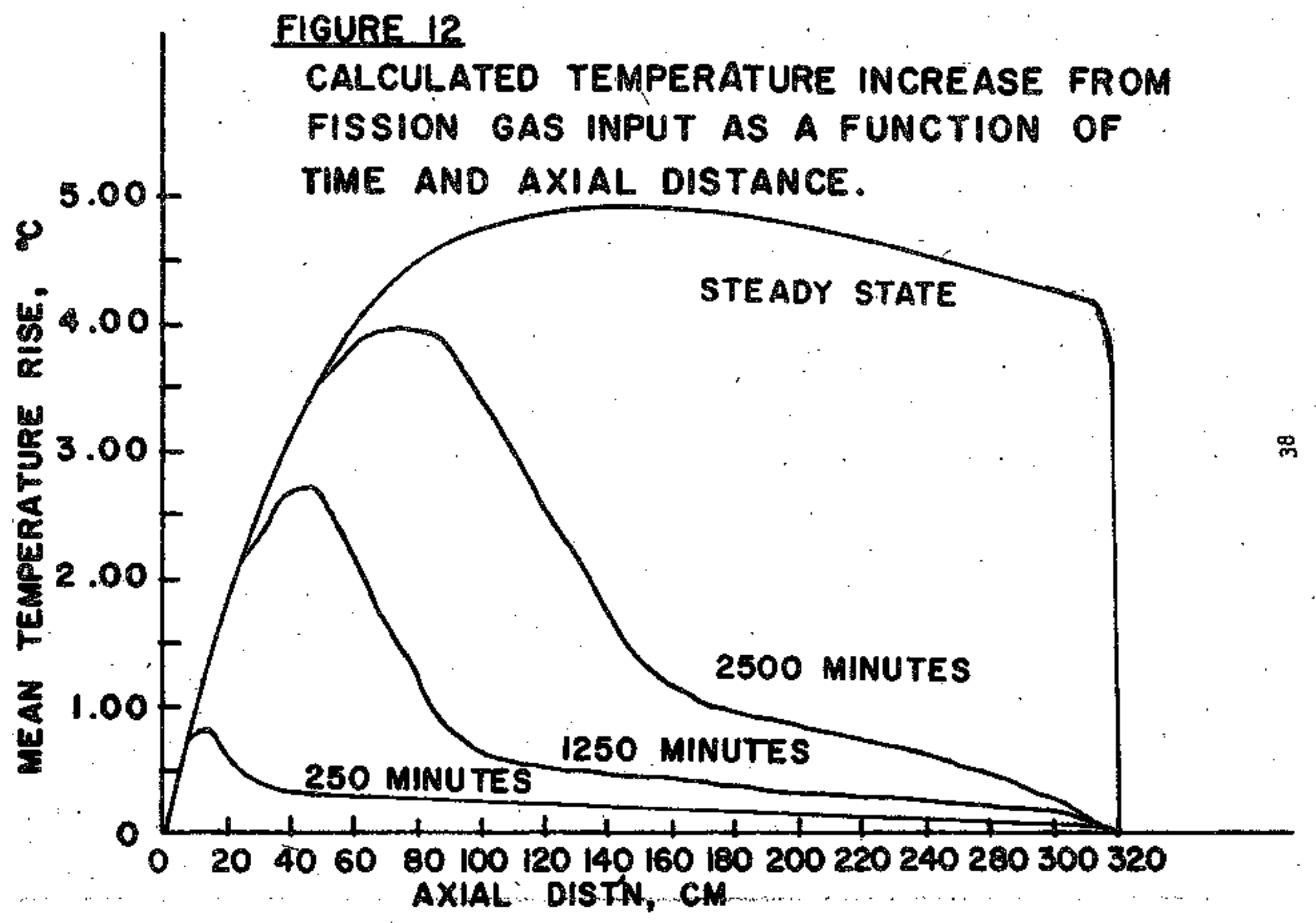


Table 20

VALUES USED TO CALCULATE TEMPERATURE INCREASE

IN A FISSION GAS ADSORPTION BED

Bed Length * $310 \mathrm{~cm}$

Bed Diameter $=90 \mathrm{~cm}$

Thermal conductivity of Argon + Charcosl $=0.00021 \mathrm{cal} / \mathrm{em}-\mathrm{sec}-{ }^{\circ} \mathrm{C}$

Heat Capacity (per unit volume)

of Charcoal

of Argon

$0.085 \mathrm{cal} / \mathrm{cm}^{3}-{ }^{\circ} \mathrm{c}$

$0.000194 \mathrm{cal} / \mathrm{cm}^{3}{ }^{\circ} \mathrm{c}$

Adsorption Coefficient (volume/volume)

for Krypton $14 \mathrm{cc} / \mathrm{cc}$

ror Xenon

$250 \mathrm{cc} / \mathrm{cc}$

Flow of Argon

$1610 \mathrm{cc} / \mathrm{sec}$

F1ssion Gas Data:

\begin{tabular}{|c|c|c|c|}
\hline Isotópe & $\begin{array}{l}\text { Cur1es Released } \\
\text { per day }\end{array}$ & $\begin{array}{l}\text { Inttial volume } \\
\text { production of } \\
\text { decay heat. }{ }^{q} \mathrm{I} \\
\text { cal/cc-sec } \\
\quad \times 20^{-8}\end{array}$ & $\begin{array}{l}\text { Linear decay } \\
\text { constant to } \\
\mathrm{cm}^{-1} \times 10^{-4}\end{array}$ \\
\hline$x e-13$ mm & 1.392 & 0.055 & 66.8 \\
\hline$x e-133 m$ & .03369 & 1.9 & 34.8 \\
\hline$x e-133$ & 676.50 & 29 & 15.1 \\
\hline$x e-135$ & 3420 & 481 & 20.90 \\
\hline$K x-83 \mathrm{~m}$ & 235.86 & 0.27 & 128 \\
\hline$k r-85 m$ & 391.50 & 5.2 & 50 \\
\hline $\mathrm{K} r-85$ & .026 & 0.000283 & 0.0023 \\
\hline $\mathrm{K}-87$ & 679.20 & 46 & 160 \\
\hline$K r-88$ & 824.40 & 53 & 78.5 \\
\hline
\end{tabular}


Table 11

COMPARISON OP NUMEFTC AND ANALYTIC SOLUTTONS FOR THE AVERAOE INCREASE RESULTING FROM DECAY HEAT

Note: For numeric analysis $\Delta x=1 \mathrm{~cm}$ and $\Delta \mathrm{x}$ 15,000 sec see text for boundary conditions.

Distance from
Inlet, cm
Calculated Temperature Increase ${ }^{\circ} \mathrm{C}$

\begin{tabular}{cc}
\hline Numeric & Analyt1c \\
0.0 & 0.0 \\
21.52 & 21.52 \\
22.78 & 22.79 \\
104.79 & 104.80 \\
462.22 & 462.39 \\
453.67 & 458.39 \\
353.74 & 389.93 \\
81.26 & 383.34 \\
0.0 & 382.61
\end{tabular}


REPERENCES

1. First, M. W., Underhill, D.W., Tadmor, J., Hall, R.R., Ratney, R.S., Baldwin, T.W., and Moeller, D.W., "Sem1annual Progress Report, Harvard Alr Cleaning Laboratory", March 1, 1971-August 31, 1971, Report Number WY0-841-25, 1ssued November, 1971, Boston, Mass.

2. Flrst, M.W., "Underhill, D.W., Hall, R.R., Baldwin, T.W., and Moeller, D.W., "Semtannual Progress Report, Harvard Alr Cleaning Laboratory", September 1, 1971-February 29, 1972, Report Number CO0-3019-I issued Apr11, 1972, Boston, Mass.

3. FIrst, H.W., Underhill, D.W., Ratney, R.S., Jochem. E., Hall, R.R., Baldwin, T.W., and Moeller, D.W., "Bemiannual Progress Report, Harvard A1r Cleaning Laboratory", Narch 1, 1972-Augist 31, 1972, Report Number Co0-3019-3, 1ssued October, 1972 , Boston, Mass.

4. Underh111, D.W., Hal1, R.R., Gold, A., Goldin, A, First, . M.W., and Moeller, D.W., "Semiannual Progress Report, Harvard Air Cleaning Laboratory", September 1, 1972December 31, 1972, Report Number co0-3019-4 1ssued February, 1973, Baston, Mass.

5. Viles, F.J., Jr., HImot, P., and First, H.W., "H1gh Capacity - High Efficiency Filters for Sodium Aerosols", Report Number NYO-841-10, Harvard School of Public Health, August, 1967 , Boston, Mass.

6. Young, D. and Crowell, A., "Physical Adsorption of Gases", Butterworths, "London, (1962).

7. Ratney, R., and Underhill, D., "The Effect of High Pressure and Low Temperature on the Adsomption of Xenon and Krypton from Helium and Argon streams", Proceedings of the 12th AEC Air Cleaning Conference, Oak R1dge, Tennessee, (August 28-31, 1972).

8. Glueckauf, E., "Long Term Aspect of F1ssion Product D1sposal", in 1st International conference on the Peaceful Uses of Atomic Energy, Vol 9, p. 3, United Nations, New York, (1956). 
9. HeIllroz.,R.W., Olueckauf, E., de Nordwall, H.J., and Pummery, F.C.W., Proceedings of the 2nd Intermational Conference on the Peaceful uses of Atomic Energy, Vol. 18, pp. 190-199, United Nations, New York, (1958).

10. Ste1nberg, , and Hanow1tz, B., BNL 493 (T-115), February, 1958 .

11: We rner, L., DP-RCport 290 AERE, Winfrith, England, March, 1965. (And many others).

12. Bendixsen, C.L., Offutt, G.F., and Wheeler, B.R., Trans. Am. Nucl. Soc. 12:497-8 (1969).

13. Skarstram, C.W., U.S. Patent No. $2,944,627$.

14. Kawazoe, K. and Kawa1, T., Kagaku Kogaku 37:288-294 (1973). (In Japanese w1th English summary.) 